\title{
Teaching
Anthropology
}

2021, Vol. 10, No. 4, pp. 36-46

\section{Glitching the University Machine}

\author{
Zouhair Hammana ${ }^{1}$ and Victoria Louisa Klinkert ${ }^{2}$ \\ ${ }^{1}$ Erasmus University Rotterdam. $2 S O A S$ University of London
}

\begin{abstract}
In this piece we explore how to return anthropological study to common use by way of Hilal and Petti's (2019) use of al masha - a cultivation and reactivation of the commons. In doing so we recognise that our point of departure is one of colonial permanence, as anthropological study is tied to the discipline and its colonial disciplining, which in turn is tied to the University Machine and its infrastructure. In enacting colonial permanence and holding up its decolonial facade it is the sociality of the infrastructure that we have chosen to focus on. We argue that it is in moments of refusal to engage and challenge infrastructural failures of the University Machine, that we find a fugitive poetic potential to glitch (Berlant, 2016; Luchkiw, 2016; Russell, 2020) anthropological study to common use.
\end{abstract}

Keywords: Glitching, decolonizing, al masha; the university, the commons

\author{
"Because the machine will try to grind you into dust anyway, whether or not we speak."$$
\text { - Audre Lorde (1984) }
$$ \\ "Last wish: I wish I had two more wishes \\ And I wish they fixed the door to the matrix, there's mad glitches." \\ - MF DOOM (Madvilian) (2004)
}

\section{Introduction}

There might be an irony that the two of us met at a decolonial summer school a few summers ago, and that the both of us work and study in and seemingly for the university, whilst writing a piece that is highly critical of the academy and certain in its ambiguous stance toward the meaning of 'decolonisation'. To us it is no irony, merely a potent point of departure to think, work, study and feel through the seemingly ambiguous, contradictory and indefinite infrastructures upholding current systems and modalities. It is especially in the recent resurgence of calls to decolonise the university and to decolonise anthropology and their subsequent inevitable (neo)liberal co-optation, reappropriation and performance, that we wish to interrogate the liberatory and poetic possibilities of (anthropological) study that are, and must be, out of reach of the university's infrastructure.

We position ourselves within the European University (Zouhair in the Netherlands and Victoria in the UK) and want to emphasize that in this piece we are focusing on this very specific geo-political and historical context. Despite being aware of more liberatory, perhaps even decolonial, models of the "university" elsewhere, we refrain from that analysis as we wish to neither reform nor decolonise this European University, but simply provide our approach to navigating and eluding its infrastructure. Both firm proponents of positionality and reflexivity being a process rather than the performative tick-box ritual it has become for many anthropologists, we still acknowledge the need to position certain facets of our identities. This is to go against a predominant "ego-politics of knowledge" which hides the speaker and decouples them from their epistemic standpoint, creating preconditions to lay claim to (a myth of) universal Truth; an epistemic strategy crucial to ensure dominance and oppression (Grosfoguel, 2007). Victoria is a white, cis, female, middleclass, queer, German PhD candidate in Anthropology at a British university and Zouhair is a Maghrebi, cis-het, male, coming from a working class background, Moroccan PhD candidate in Sociology at a Dutch university. We work in dialogue and across positionalities which lays the foundation to retain a more processual reflexivity, by a consistent questioning of where each one of our knowledges and standpoints is coming from and how it leads us to an awareness 
and accountability of the study we do together. For us it is also a way to counteract the violence of individuation enacted upon us by the university machine.

We perceive the University to function as a machine that enacts colonial permanence and inevitably so does anthropology, because of its dependency on the University and its colonial continuity of disciplining. Anthropological study is to us a doing, thinking and feeling that transcends the classroom, the field, or the books, and it is one that ought to be anticipated in the in-between spaces. There are three principles of anthropological study we have anticipated, particularly in those in-between spaces, that we believe have liberatory leanings and are of 'use'. These three principles are in no way a reduction of anthropological study to merely three points, but it is rather a way for us to grasp and attempt to translate what we mean when we say anthropological study. We think that coloniality separates, divides, breaks-down and individuates study, which we believe has happened and is happening to (anthropological) study. Thus, we argue that to 'decolonise' the University's enactment of colonial permanence on anthropological study, means to return anthropological study back to (its) common use and cultivate it through common use in the modality of al masha (Hilal \& Petti, 2019).

We will explain what we mean with 'common use' and 'return', and their relation to coloniality and decolonising, in the second section (II) of this paper. Returning to common use needs to be done away from the prongs of the University's infrastructure, an infrastructure that functions to uphold the machinery of a colonial blueprint. By delving into an example of a University's infrastructural failing, that is to say an example of the University Machine showing face, we explore what it means to challenge and/or refuse to engage in this infrastructural failure, and to engage in a poetics of refusal in the third section (III) of this paper. A refusal that is best formulated as "failing that which has had and is failing us". A refusal as feeling and making that takes place in the in-between spaces and places, in which anthropological study is being returned to common use, in the practice of glitching (within) the University Machine. Glitching (Berlant, 2016; Luchkiw, 2016; Russell, 2020) is a way to slip over and in between the cracks of the machine, to gloss over its structure and to refuse to engage in its supposed failure and celebratory 'decolonial' gloss over. It is a practice of revealing the infrastructural failures and interrupting the transmissions within the University Machine's infrastructure (Berlant, 2016). Glitching is to engage in al masha and cultivate anthropological study together away from the University Machine and its pitfalls and traps of infrastructural discourses of decolonising the University and decolonizing anthropology. We will explore what this means in-depth in the fourth section (IV) of this paper.

\section{Al Masha and return(ing) to common use}

Sandi Hilal and Alessandro Petti think about decolonisation through Agamben's notion of the profane and profanation, in which they conceptualize decolonisation as ".... counter-apparatus to restore to common use what the colonial order has separated and divided" (Hilal et al., 2011, p. 2). Profanation is, according to Agamben, "restoring things to their common use" (Agamben, 1942). Returning to common use is to us an interesting formulation when thinking about decolonisation. Stevphen Shukaitis remarks in a conversation with Stefano Harney and Fred Moten, about their forthcoming book All Incomplete, that "....rather than talking about how to make things common, it's more the case that that's their default state, that sharing is the default. Rather it's the default sharing which needs to be broken down and individuated" (Moten et al., 2021, p. 8). We think that that is precisely what the colonial order does, the colonial order 'separates and divides' (Hilal \& Petti, 2019) and it 'breaks down and individuates' (Moten et al., 2021). When we think about the University and decolonising the University, we think about the ways in which coloniality has separated, divided, broken down and individuated us from each other and from study within the University. To us 'decolonising the University', and with it by extension 'decolonising Anthropology', is not necessarily a move towards the commons. Rather, to us, it is a return to common use, a return of Anthropological study to common use. To the state that comes before the separation, divide, break-down and individuation that the colonial order, and perhaps more precisely, the ongoing colonial permanence (Simpson, 2017), has so violently done. Thus, we turn to Hilal and Petti's (2019) definition of decolonisation. We do not wish to make a grand statement on decolonising the discipline or the University in the vein of overturning their coloniality. We believe this to be beyond the scope of this paper, and impossible to accomplish in this format and within the reach of the prongs of the University. Context matters and each apprehension of decolonisation has its very own, and we deem this one to be most apt for our attempt to counter individuation and to profane. 
To profane to common use is a return not in a way of going back, the University, and especially Anthropology, never had a decolonial point of departure. But in the way of giving back, of restoring study, restoring anthropological study, and returning it to the common, or more precisely, to return study, to return anthropological study to common use. When we say 'return' we are indebted to the thinking and writing of Sarona Abuaker (2020) who writes about a queer return(ing)--in the context of the Palestinian struggle in the face of ongoing Israeli settler colonialism-as a way of arriving, rather than 'going back'. Returning anthropological study to common use is a move towards an arrival of giving back, an arrival in giving back, an arrival that is always moving, or what Abuaker (2020) calls a queer return(ing). This return(ing) to common use is a way to resist the ongoing violent separation, divide, break-down and individuation that happens within, and also because of, the western modern anthropological discipline(s). So, thinking with Tuck and Yang (2012), and with Bhambra, Gebrial and Nişancioğlu (2018), perhaps the only possible formulation of putting decolonisation together with University in the same sentence, and by extension putting decolonisation together with Anthropology in the same sentence, is to see decolonisation 'as the counter-apparatus to restore to common use what the colonial order has separated and divided', to profane and to return anthropological study to common use.

It is important to note that we rather speak of 'returning to common use' than the Agambenian 'restoring to common use' (Agamben, 1942). Although we think when Agamben, Hillal and Petti write about 'restoring' that they are not speaking of some kind of move toward a conservatism, rather perhaps a move of conserving, but more aptly, 'restoring' here has to be read together with 'common use' and therefore should be read as 'to (be) put again in possession of something'. However, we do prefer to use 'give back (to)' instead of 'to restore (to)', precisely because 'giving back (to)' seems to us to be a formulation that is closer to our argument. This is in no way to say that Hilal and Petti's formulation of 'to restore to common use' is a wrong formulation, the contrary, we believe that their formulation in the Palestinian context is incredibly apt. We are just wary of a 'fetishism of the past' that seems to surround certain decolonial moves toward restoring, and thus prefer to speak of a 'giving back to common use' to clarify that, to us, the move toward collective cultivation is what we precisely mean. It is the queer return(ing) that Abuaker (2020) speaks of, a return(ing) as a way of arriving, a return(ing) that completely does away with any linear colonial understanding(s) of temporality. In other words, to 'decolonise Anthropology', or rather, to 'decolonise anthropological study', is in our understanding to give anthropological study back to common use. To queer 'retur(ning) to common use' to us also does away with the dichotomisation of study within the University versus outside the University. It emphasises the in-between spaces, the ambiguity and even the discomfort of navigating these dichotomies. We neither argue that we return study to common use from within the University to beyond its walls, nor vice versa. This would imply a certain arrogance to (anthropological) study and crystallise an essence to study that is located either outside or within the University Machine. Being involved in study within and outside and within but not of the University, we simply would like to return study to common use in the spaces that we find and that find us. It is not a question of access in the sense of having to access the University Machine before you are able to join (in) study, it is the contrary, the study we are referring to has been moving, moves, and will continue to move outside of, underneath, over and through the University Machine. If any, us 'academics' have difficulty 'accessing' study. To be able to have access to study would mean that study is demarcated and bordered, closed off and territorialized, this would be antithetical to what study is, which is to say, in a sense, that we cannot access study because study is not accessible. It is not accessible because it is not closed off. What we deem "anthropological" study then, is not a form of study inherent to anthropology but merely the tenants of study we find within the discipline that we perceive to be resonating with the poetic possibilities of study we are referring to.

And here we are consciously focusing on "study" and not epistemology, as it combines thinking, learning, theory, practice and teaching. Study is a way of being, and being together, but also a way of doing and feeling. Anthropological study is then a sort of anthropological moving, a(n) (un)disciplinary moving which gives rise to certain ways of thinking, doing, and feeling, with an acknowledgement that all of these are connected with one another. There is no doing without thinking and no thinking without feeling. Anthropological study, however, is not isolated. Especially if we aim to return anthropological study to (its) common use, then we cannot separate it from the University and its infrastructure, from anthropology's "human error" (Todd, 2016), and its continuous enactment of colonial permanence. The disciplining of anthropological study by the University is part of the colonial project. Anthropology has historically been used to enact colonial discipline (Asad, 1973; Lewis, 1973; Mullings, 2005), and it continues to be used to enact colonial discipline, in all its extractivist and oppressive dimensions, and in turn disciplining anthropological study into a mold for colonial discipline. In short, we cannot separate the colonial 
infrastructure of the University from anthropology, but can we return anthropological study to common use?

To answer that question we have to ask a couple of other questions. What is the purpose of returning anthropological study to common use? What is it about anthropological study that is useful to common use? Is useful even the correct word? If we unearth the liberatory potential of alternate anthropologies and what have been deemed decolonial anthropologies, then we have excavated these three principles of anthropological study: its intersubjective nature and potential of knowledge creation (Harrison, 2016), its potential of an acknowledgment, a celebration and an enactment of pluriversality (Escobar, 2018), and its ability to situate lived experiences into processes and networks of power -which when removed from the prongs of the universities' infrastructure, would be a study we wish to return to common use.

Hilal and Petti use the Arabic concept al masha, or 'the return to the common', in which al masha is a form of relating to the land, a form of indigenous relation to the land, in which the land is governed, or rather cultivated, through common use. Al masha as shared land originated as a practice throughout the Islamic world, as a combination of "conceptions of Islamic property and customary practices of communal or tribal land" (Petti \& Hilal, 2013). Hilal \& Petti (2019) define al masha as:

The Arabic term al masha refers to communal land equally distributed among farmers. Masha could only exist if people decided to cultivate the land together. The moment they stop cultivating it, they lose its possession. It is possession through a common use. Thus, what appears to be fundamental is that, in order for this category to exist, it must be activated by common uses. Today we may ask if it is possible to reactivate the cultivation of the common, expanding the meaning of cultivation to other human activities that imply the common taking care of life. The Arab Revolts that started in 2010 have shown various ways in which al masha can be reclaimed and reactivated. (emphasis added) (2019, p. 2)

What if we approach study, and in this context more precisely anthropological study, through that proposition, through the proposition of whether it "is possible to reactivate the cultivation of the commons, expanding the meaning of cultivation to other human activities that imply the common taking care of life" (Hilal \& Petti, 2019)? Is study not an activity of 'common taking care of life'? And if al masha can only exist if people decide to cultivate the land together, does not that mean that (anthropological) study can only exist if people cultivate these activities of common taking care of life together, activities that we might put under the rubric of (anthropological) study? There is both making and feeling in cultivation. This means a complete, and actual, democratisation of study, one in which students have just as much say in what is studied as faculty has. One where a radical passion and passivity is creating conditions for indeterminate identity. A celebratory space where study is returned and cultivated together. It is not a coincidence that in Arabic al masha sounds and could be read as 'walking', implying a continuous moving, a moving away from individuation, separation, a moving away from colonial permanence. Walking as a way to profane, to defy permanent temporariness, to return (to) study, and to re-turn and give back study (to common use). Walking, yes. It is after all a refusal. But it is more than that. It is a walking toward, a walking as toward, a walking together and a walking through. A walking as arriving.

\section{The University Machine}

How can we return anthropological study to common use, while the University and its infrastructure continuously continues and reaffirms a colonial permanence onto study? How do we do this, or rather how are we doing this, while we are working inside the machine we call the University (Schinkel \& Van Reekum, 2020)? We believe the University functions very much as a machine, a machine that continuously produces professionals and more importantly, continuously produces credentials. The modern Western (neo-liberal) University is a credentialization machine. A machine with an (violent) infrastructure. An infrastructure we have to navigate through each and every day when working, studying, playing, within and around the University. An infrastructure through which anthropological study becomes separated, divided, broken-down and individuated through coloniality. As the late Lauren Berlant (2016) puts it, an infrastructure is not to be confused with a system or structure, but rather, as Berlant would say, an "infrastructure is defined by the movement or patterning of social form. It is the living mediation of what organizes life: the lifeworld of structure" (Berlant, 2016). This patterning of social form within the University becomes visible when we look around in and through the University walls. The University infrastructure is made up of different experiential cogs, dresses, jargon(s), seminars, wine, performances, book launches, departments, 
statements, hiring practices, disciplining, teachers, students, the critical academic, the coffee machine, ID cards, office hours, diversity and inclusivity statements, emails, administration, policing, and the list goes on. These are all continuously oiled and are oiling, with what can only ever be extractivist oil, to ensure the smooth reproduction and continuation of its colonial machinery, of its colonial infrastructure, which is to say it is continuously reaffirming colonial permanence.

However just like machines are prone to errors, so too is the University Machine prone to infrastructural errors. Take the case of a comment of a liberal/critical academic for example. Liberal and critical here are used as interchangeable, as in anthropological study a presumption of criticality is the trademark par excellence of liberalism (Jobson, 2020; Ahmed, 2012; Brodkin et al., 2011). Part and parcel of the University Machine, embedded in and upholding the infrastructure, they all seem to slip at one point, we have all seen it, heard it, felt it. All of a sudden they slip, the racism is out (of) the bag, the colonial permanence makes its presence felt, overtly, revealing its colonial coding. Whether it is in the iteration of "oh I didn't realise you [a student of South Asian heritage] are from Austria?", or, declaring in relation to falling statues "but we should respect all sides!", or, asking what it is like to do anthropology "at home" to the non-British but white student conducting fieldwork in the UK, when all other participants are conducting fieldwork in their respective, racialised home countries, or, in declaring a relativity to racism, or, in being spoken to in English on campus while your non-Dutch white colleague is spoken to in Dutch, or... and the list goes on and on like the cogs in a machine. Right after that the teacher utters $i t$, it often is met with silence. But not any kind of silence. A heavy silence. The air thickens and the presence of whiteness becomes palpable. You can almost touch it. Then straight away there are ephemeral glances of recognition, an immediate intersubjective reassurance. A way to communicate without words, what has just happened and to counter what Sara Ahmed (2012) often calls the 'paranoia' of racism, or racism's paranoia. But these glances, fugitive in their nature, are timed and coordinated in ways so as to not be noticed. They are strategically camouflaging from the gaze of whiteness and its potential retaliation in the form of white shame (Kwon, 2020; Sullivan, 2014), white guilt (Lorde, 1997), white fragility (DiAngelo, 2018; Todd, 2016) or white discomfort (Zembylas, 2018). Whether it is the narcissistic apology, the attempt at justification by referring to a presumptive liberal Boasian antiracism (Jobson, 2020; Simpson 2018), or a deferral of responsibility to "the racists over there", or a destructive outrage at being linked to racism, or, you know, a good old white tear.

Then there are too, of course, the averted gazes adding to the stiffness of the situation. For one, the ones looking at one's lap, heavy with white shame or guilt - and just waiting for the moment to pass and the discomfort to vanish, inhibiting feeling and wishing that they had never penetrated through the infrastructural façade, right into the colonial blueprint, proceeding to pretend that they never have seen past the facade and thus enabling a continuous delusional 'decolonial decorating' of the machine's casing. And then too, of course, the ones heavy with the burden and violence of these racist assaults, who have always felt and known that the 'decolonial decorating' of the machine's casing is but a façade. And then the moment is 'over'. All of a sudden. The teacher moves on. And it all happened so fleetingly and so forcefully that the comment goes unchallenged, and whiteness seemingly comes out stronger and reinforced. Colonial permanence is reaffirmed, again. Whiteness, the structural, epistemic and cognitive moral source that has justified coloniality's horrors, sustains itself once again. But we all know that that moment is never truly 'over'. These moments might seem as singular events, but they are actually ongoing and are felt before, during and after, but it is in these moments that we temporarily get to see right into the colonial coding of the University Machine. The machine seemingly slipped, but it continues running and its façade is bolstered. Its infrastructure never truly failed, because this is precisely how the University infrastructure functions. What happened is merely a slip in the façade of the infrastructure, a fleeting moment that allows us a glimpse at the colonial coding deeply rooted within the infrastructural fabric of the University, hiding behind a façade, behind the façade of 'diversity and inclusivity committees'. These moments that might seem like errors are part and parcel of the emotionality but also the very affective and political structure that whiteness is built upon. They are both a crack in the wall of whiteness, and the mortar that works to solidify and ensure its endurance. They reinforce because they are met with a discursive silence. In their very moment they go unchallenged. This is for one, because of their force and fleeting nature, their suddenness and stunning quality. But, also because of the unique hierarchy of a university classroom.

They are however not silent in a poetic sense. They create an affect, they are affective. It is that affect that we want to think with. What does it tell us? How can it lead us to a poetics of refusal? Who perceives these moments, who is 
attuned to them, and who feels them viscerally? Many won't be attuned or aware, for those who are not aware, it is a kind of affective form of white ignorance. How to counter this ignorance and spur affective attunement is one question, it's flipside is white ignorance's' "moral cognitive dysfunction", as the late Charles Mills (1997) calls it, and one that needs to be addressed on an emotional level too (here we are thinking with the luminous James Baldwin and Toni Morrisson and their focus on the sociopathy of whiteness). There is, however, also an added difficulty of institutionalised hierarchy and conditions of precarity and dependency of the neoliberal University Machine involved in this silence. Who will get the next teaching gig? And who, as in which professor, has the power to decide? But here too of course are racialized differences to precarity, and very concrete different political, material and psychological and sociological realities.

There is also the question of how much a challenge would change the structure and how much it would serve to reinforce and solidify and oil the machinery and its re-appropriative prongs. "Because", and here we quote Harney \& Moten (2013),

critical education is precisely there to tell professional education to rethink its relationship to its opposite - by which critical education means both itself and the unregulated, against which professional education is deployed. In other words, critical education arrives to support any faltering negligence, to be vigilant in its negligence, to be critically engaged in its negligence. It is more than an ally of professional education, it is its attempted completion (p. 32).

Attempting to call out and educate your critical/liberal professor, who might then take on the critique in a performative, or as Sara Ahmed (2012) would say, non-performative way, runs the risk of bolstering critical education which according to Moten and Harney is what sustains the University Machine and its exploitative infrastructure, it oils and reinforces the machinery.

There are of course other ways that these comments/moments, granting us temporarily to see right into the colonial coding of the University Machine, do not go unchallenged. Yet, crucially these moments of understanding, of (anthropological) study, happen outside the reach of the University's infrastructure and its enactment of colonial permanence. The affect lingers and remains, it imprints itself and at times is harnessed to challenge and confront racism in the academy -but with a temporal delay. At a later date. But it can, especially if jointly reflected on afterwards, create a collective memory and institutional infrastructural map of where these racist incidences can occur, who perpetuates them and how possibly to challenge or shield. Some of these experiences have been akin to a fugitive sense of understanding, enabling a move away from the University and what we call glitching study to common use. The work that we do when we refuse the reaffirming of a colonial permanence, must be work that is done through a poetics of refusal, a refusal through 'making' and 'feeling', which is to say that poetics is always making and feeling at the same time, and refusing always moves through an act of making and feeling. These joint reflections, cultivations of al masha, echo what Moten and Harney describe when they say "But we would ask what is already not possible in this talk in the ballways, among the buildings, in rooms of the university about possibility?" (Harney \& Moten, 2013, p. 30). It is a poetic possibility, making and feeling in spaces of refusal, a cultivation of study, of anthropological study and its intersubjective potential of knowledge creation, its pluriversal potentiality and ability to situate the lived experience in structures of power - we whisper, we laugh, we cry - yet, crucially (temporarily) out of reach of the prongs of the machine. If we were to detail them further, it would be both an act of voyeurism as well as duplicity by luring the prongs right into these spaces. Still, no one is refused. It happens here and there and everywhere. We glitch. By coming together in the hallways, the reading groups, the backrooms, courtyards, and even right in front of everyone's eyes, we sit, talk and feel through these structures of colonial individuation and cultivate together a study which helps us navigate the violence of the University Machine. We do not wish to romanticise these moments, nor deny their absolute violence, but in pointing out the potentiality and poetics of refusal in some of these instances we wish to make visible the practice of glitching anthropological study back to its common use. The practice of 'failing that which is failing us' (McCulloch, 2021).

\section{Glitching (to common use)}

The University Machine and its infrastructure enact colonial permanence. It is coded into the University, its blueprint is a colonial code. It is however prone to error and in those moments its infrastructure fails to uphold its liberal casing which these days has been adorned and decorated with anti-racist and decolonial illusions, and then reveals its 
colonial coding. However brief that moment might be. Delving into the possibility of errors we believe that we can and have been, using these errors ourselves, to 'decolonise' (anthropological) study through what we call glitching study back to (its) common use. A glitching that is done continuously to foster spaces in which study can be cultivated together, it has to be done continuously (Alagraa, 2021) because the struggle for liberation is a long one. This is why Leanne Betasomasake Simpson (2017, p. 153) writes: "If we accept colonial permanence, then our rebellion can only take place within settler colonial thought and reality", which is precisely why colonial permanence reaffirmed by the University Machine, which is to say by the modern Western University, must be continuously refused through a practice of returning study to common use. As we have always attempted to do, we hope that we can continue to slip, glide and hitch through and from the University Machine and its infrastructure in a collective manner to find spaces in which we can cultivate study together.

The University Machine and its infrastructure are prone to error. We refuse to fix and restore these errors, as Berlant (2016) points out "resilience and repair don't necessarily neutralize the problem that generated the need for them, but might reproduce them". Instead of working with or against these 'glitches', we are doing the actual glitching ourselves. Is it not in these fugitive moments in the hallways, among the buildings, during our anti-racist and decolonial reading groups, the moments before and after class, that our collective refusals lead study back to (its) common use, where anthropological study has liberatory leanings? Or as Legacy Russell $(2012,2020)$ puts it when she writes about Glitch Feminism:

Glitch Feminism, however, embraces the causality of "error", and turns the gloomy implication of glitch on its ear by acknowledging that an error in a social system that has already been disturbed by economic, racial, social, sexual, and cultural stratification and the imperialist wrecking-ball of globalization-processes that continue to enact violence on all bodies - may not, in fact, be an error at all, but rather a much-needed erratum. This glitch is a correction to the "machine", and, in turn, a positive departure. (2012, para. 8)

Russell, in an interview with Sara Black McCulloch (2021), continues by saying " [t]he discussion of failure is essential here: what does it mean to "fail" in a society that fails us? Can this failure to perform and abide by the hegemonic and supremacist standards of this current world order be an opportunity? A rerouting?" Which is to say, if asked differently, "what does it mean to "fail" in a University/Discipline that fails us'? Can that failure of us function as a rerouting, as a way to return anthropological study to common use?

When we speak of glitching, we do this partly by way of Berlant (2016, p. 393), who writes: "A glitch is an interruption within a transition, a troubled transmission. A glitch is also the revelation of an infrastructural failure." In a machine where we are already viewed as 'faulty', 'problems', 'nuisances' and 'failures', the work that we try to do within and outside of the classroom interrupts the transmissions within the University. We are failing that which failed and is failing us. These interruptions can be seen as a practice of glitching the University Machine and not as mere passive glitches within the University Machine. To profane anthropological study, to decolonise study, to practice a continuous refusal of colonial permanence, then becomes a practice of glitching study to common use. A return(ing) not in the way of going back, but in the way of giving back. Anthropological study must be given (back) to common use, within the University Machine it must be 'glitched to common use'. Glitching can be etymologically traced back to the German word 'glitschen', which could be translated as slipping or gliding. 'Glitching to common use' then becomes a practice of 'slipping', 'gliding' and 'returning' study to common use, while working within and against, by being in but not of, the University Machine. These little slips, hiccups, or maybe what Fred Moten would call hesitancies, or hitches, are the things we do within the University Machine when we try to return study to common use, when we try to glitch the University Machine. Within the world of video games, glitching is a well known term, it is an active practice of looking for flaws, glitches, that can be exploited to achieve something that was not initially intended by the software designers, the game designers (Bainbridge \& Bainbridge, 2007; Švelch, 2015). In our understanding, when we are trying to return (anthropological) study to common use, we are looking for flaws that we might use to return (anthropological) study to common use, something that was not intended by the 'game designers'. We are looking for ways to fail the Discipline and the University Machine, that have and continue to fail us. We do not see glitching as an ontological state, we do not think that we, as we are working within the University Machine, are glitches, instead we think that glitching is a practice that has the potential to hiccup the University Machine, a practice that allows us to slip through and from, to glide through and from, the University Machine in order to return, as in to give back, study to common use. To return it to the social modality of cultivation. Which is to say that glitching is a continuous refusal of colonial permanence to return study and education to al masha, to a 
modality in which study is cultivated together and exists in the relationality of whomever is cultivating it. Existing in sociality. Juliana Luchkiw (2016) writes:

However, glitches crack open these hierarchies by disrupting the structure that establishes them. A glitch of the system is not only a metaphor or an allegory in this sense but also has the capacity to affect and effect. (p.3)

Glitching allows us the possibility to 'crack open the hierarchies by disrupting the structure that establishes them' (Luchkiw, 2016), it allows us to crack open the hierarchies within the University Machine, however briefly that crack may be. Glitching allows us to resist the hegemonic structures by 'interrupting the transmissions', 'revealing the (intended) failures' and 'cracking open the hierarchies' of and within the University Machine. So, with each and every turn of the University Machine, with every turn and re-turn of its cogs and wheels, we try to return study to common use through a practice of glitching. By profaning study from credits, from creditization, from certificates and certification. However, we do not neglect the importance of these unimportant milestones for the students to be able to live in a political economic governance that makes living difficult, if not, impossible. But we treat study as a modality of sociality that can only be cultivated together in relationality, whilst not hindering, nor policing, or administrating as little as possible the experiential package (Moten \& Harney, 2020) laid out by the University Machine. Which is actually to say that by not policing or by not trying to do administration (we must not forget that administration $i$ s policing), we are attempting to glitch study to common use, an activity of human taking care of life that has been commodified and corrupted by the University Machine. We are attempting to glitch study to a cultivation of a human activity of life that is done together. The little slips, hiccups and hitches are the spaces in which we do our work against the University Machine, while working in and for it. Spaces that define how we are in but not of, how we are in the belly of the beast but not of it, how we are in the University Machine's casing but not of it, a casing regulated by the fatherboard, because we cannot separate patriarchy from racial capitalism and colonialism.

This is of course something that, as Leanne Betasamosake Simpson (2017) would say, we have always done. The 'we' here is not just us, the authors, but the 'we' here is referring to a collective of whomever is working within and against the University Machine in a pursuit of liberation (if we, Victoria and Zouhair, might so presumptuously use that 'we'). This is an analysis of the potentiality of that which some of us have been doing all along, whom have been slipping, gliding, hitching and hiccuping through and from the University Machine, whether it be in the classroom, hallways, 'office hours' or outside of the University walls. However, this returning to common use, these attempts to cultivate study together as an act of human taking care of life (Hilal \& Petti, 2019), has the potentiality to be a way to work with and through the contradiction(s) of working within the University Machine and simultaneously against it. To radically take these instances of slipping, gliding and hitching to actively work towards glitching study to common use, to al masha, that, as Hilal \& Petti (2019) write:

"...exists beyond state institutions. The public is a space that is given to people by structures of power, whereas al masha is a space created by the interaction of people. Public space can exist without people. Al masha only exists if people are constantly producing it." (p. 2) (emphasis added)

To return, or rather to glitch, study to a modality of al masha in which anthropological study can only possibly exist if people are constantly producing it together, precisely because it is a space that is created by and through the interaction(s) of people.

Glitching crosses over structure, glitching interrupts transmission, glitching does not take order serious, glitching can not be oiled, nor does glitching oil. Glitching the University (Machine) must mean that disciplinary ordering must be refused. It means to refuse disciplining. Or rather, the Discipline needs to be abolished. While we are working in the 'belly of the beast', or the 'casing of the machine', a move away from disciplinary thinking is important when thinking about the refusal of colonial permanence. This means that Anthropology reaffirms colonial permanence (as Todd, 2016; Jobson, 2020; Shange, 2019 amongst others have said). It means that Sociology reaffirms colonial permanence. And so on. This, however, does not mean that anthropological study, and sociological study, cannot be useful and important, it absolutely can. It means, however, that the Discipline 'as is', cannot. Precisely because, as Linda Tuhiwai Smith (1999) teaches us, a discipline is not only a way of organizing systems of knowledge, but also a way of organizing people and bodies. And as Rinaldo Walcott (2020) aptly points out: 
The development of fields such as criminology and security studies emerging from sociology (and political science) should give us pause. The discipline is as complicit with forms of institutional violence as those of campus police, city police, and other private police. All those forms of policing take as an unquestioned assumption that black people are a dangerous threat in need of management. All those forms of policing are founded in antiblack racism. All we can do intellectually is to let them die, to destroy their relevance as arbiters of life, and that death too means the death of sociology as a discipline. (p. 486) (emphasis added)

Which of course is to say that the Discipline must die. The Discipline must intellectually be let to die, or as Ryan Jobson ponders, it must be 'let to burn' (2020). And with it its relevance must be destroyed, because the Discipline and the disciplining reaffirms colonial permanence with each and every line it violently draws to mark its borders. We must however make sure, as Avery F. Gordon (1997) tells us, that the ghost of The Discipline does not come (back) to haunt us. Which is why when speaking about abolition, it is important to think with and learn from the work of Ruth Wilson Gilmore. Ruth Wilson Gilmore theorizes abolition as not just the absence of things, but also about the presence of things, about "building life-affirming institutions" (Gilmore, 2007). In other words, it is not only about the destruction of things, but also about working on and building non-violent alternatives to those things. These can go hand in hand. This is not to say that we need alternatives to disciplines, this is to say that the work we (can) do beyond the borders of the Discipline is precisely that alternative and simultaneously the (intellectual) death of the Discipline.

\section{Conclusion}

The move of a refusal that we engage in when working within the University is not merely a passive glitch within the University Machine and its colonial infrastructure, and its colonial coding, it is an active practice of glitching study to common use in the sense that approaching studying within the classroom (and outside of it) through 'making' and 'feeling', is an attempt at fostering a space, or space between spaces, to study against the grain of colonial permanence. There is a need to combine making with feeling as a radical act, a way to overcome subjectivity, a being together that understands that action is always necessarily tied to feeling as we all are in our fugitiveness. What the space of study then necessitates, is a space beyond teaching, a practice that has care at its core (Mehta, 2019; Ahmed, 2016; hooks, 1989), in which affective attunement, feeling and cultivating together becomes a precondition. Or, as Moten \& Harney (2013) put it:

What the beyond of teaching is really about is not finishing oneself, not passing, not completing; it's about allowing subjectivity to be unlawfully overcome by others, a radical passion and passivity such that one becomes unfit for subjection, because one does not possess the kind of agency that can hold the regulatory forces of subjecthood, and one cannot initiate the auto-interpellative torque that biopower subjection requires and rewards. (p. 28).

One way to possibly look at glitching to common use, is by continuously distinguishing between that which students might need to know or perform to pass, which is a way to allow them to navigate through the University Machine so they are able to maybe find a way to materially survive racial-patriarchal-heteronormative-capitalism, and that which we might call study, a collective endeavor undertaken together to cultivate human activities of taking care of life. In our refusal to police students it is just as important to not hinder students in their pursuit of receiving a (stable) paycheck, because a liberatory practice that does not recognize the importance of unimportant educational milestones, a practice that does not recognize the urgency of (material) survival, is in our eyes a failed liberatory practice. Making that distinction in our work is precisely the slipping through and from the University Machine, the gliding through and from, the hitching, the hiccuping, which is to say, the glitching study to common use through and from the University Machine. The work that cracks open, interrupts and disrupts transmission, reveals (the intended) failure of the University Machine. It brings us back to our seemingly ironic point of departure, that takes seriously the ambiguous, contradictory and messy nature of the infrastructures that we cannot escape but navigate, temporarily refuse and glitch. We keep on glitching through these infrastructures, attempting to refuse and resist colonial permanence by cultivating anthropological study together, whether within or outside of the University classroom.

\section{References}

Abuaker, S. (2020). Suture Fragmentations - A Note on Return. Kohl, a journal for body and gender research. 
Agamben, G. (2007). Profanations. Zone books: New York (original work published in 1942)

Ahmed, S. (2016). Living a feminist life. Duke University Press.

Ahmed, S. (2012). On being included: Racism and diversity in institutional life. Duke University Press.

Alagraa, B. (2021). What Will Be The Cure?: A Conversation With Sylvia Wynter. Offshoot.

Asad, T. (Ed.) (1973). Anthropology \& the colonial encounter. Ithaca Press.

Bainbridge, W. A., and Bainbridge, W. S. (2007). Creative uses of software errors: Glitches and cheats. Social Science Computer Review, 25(1), 61-77.

Berlant, L. (2016). The commons: Infrastructures for troubling times. Environment and Planning D: Society and Space, 34(3), 393-419.

Bhambra, G. K., Gebrial, D., and Nişancioğlu, K. (2018). Decolonising the university. Pluto Press.

Brodkin, K., Morgen, S., and Hutchinson, J. (2011). Anthropology as white public space? American Anthropologist, 113(4), 545-556.

DiAngelo, R. (2018). White fragility: Why it's so hard for white people to talk about racism. Beacon Press.

Escobar, A. (2018). Designs for the pluriverse: Radical interdependence, autonomy, and the making of worlds. Duke University Press.

Gilmore, R. W. (2007). Golden gulag: Prisons, surplus, crisis, and opposition in globalizing California (Vol. 21). University of California Press.

Gordon, A. F. (2008). Ghostly matters: Haunting and the sociological imagination, University of Minnesota Press. (original work published in 1997)

Grosfoguel, R. (2007). The epistemic decolonial turn: Beyond political-economy paradigms. Cultural studies, 21(2-3), 211-223.

Harney, S., and Moten, F. (2013). The undercommons: Fugitive planning and black study. Minor Compositions

Harrison, F. V. (2016, May 2). Decolonizing Anthropology: A Conversation with Faye V. Harrison, Part I [Web log interview by C. McGranahan, K. Roland, \& B. C. Williams].

https://savageminds.org/2016/05/02/decolonizing-anthropology-a-conversation-with-faye-v-harrisonpart-i//

Hilal, S., and Petti, A. (2019). Permanent Temporariness. Art and Theory publishing.

Hilal, S., Petti, A., and Weizman, E. (2011). Decolonizing Architecture. Sternberg Press.

hooks, B. (1989). Talking back: Thinking feminist, thinking black (Vol. 10). South End Press.

Jobson, R. C. (2020). The case for letting anthropology burn: Sociocultural anthropology in 2019. American Anthropologist, 122(2), 259-271.

Kwon, J. B. (2020). Paradoxes of white moral experience: Opaque selves, racial suspicion, and the ethics of whiteness. American Ethnologist. 47(2), 184-191. 
Lewis, D. (1973). Anthropology and colonialism. Current Anthropology, 14(5), 581-602.

Lorde, A. (1997). The Uses of Anger. Women's Studies Quarterly, 25(1/2), 278-285.

Luchkiw, J. (2016). Situating Glitches: Networks of Knowledge Production. Signal/ Noise, collected student works from a feminist docc.

Mehta, A. (2019). Teaching gender, race, sexuality: reflections on feminist pedagogy. Kobl: A Journal for Body and Gender Research, 5(1), 23-30.

McCulloch, B.S. (2021). Activating the Glitch: A Conversation with Legacy Russell. LARB

Moten, F., Harney, S. and Shukaitis, S. (2021). Refusing Completion: A Conversation. E-flux.

Moten, F., and Harney, S. (2020). The university: last words.

Mills, C. W.(1997). The Racial Contract, Cornell University Press.

Mullings, L. (2005). Interrogating racism: Toward an antiracist anthropology', Annual Review of Anthropology, 34

Petti, A., and Hilal, S. (2013), Beyond the Public, A common space in Fawaar refugee camp. Beyond the Public, 45-58.

Russell, L. (2012). Digital Dualism And The Glitch Feminism Manifesto. Cyborgology

Russell, L. (2020). Glitch Feminism: A Manifesto. Verso Books

Schinkel, W., \& Van Reekum, R. (2020). The University Machine.

Shange, S. (2019). Progressive dystopia: Abolition, antiblackness, and schooling in San Francisco. Duke University Press.

Simpson, L. B. (2017). As we have always done: Indigenous freedom through radical resistance. University of Minnesota Press.

Simpson, A. (2018). Why White people love Franz Boas; or, the grammar of indigenous dispossession. In: Indigenous Visions, (pp. 166-182). Yale University Press. https://doi.org/10.12987/9780300235678-009

Smith, L. T. (2013). Decoloniring methodologies: Research and Indigenous peoples. Zed Books Ltd. (original published in 1999)

Sullivan, S. (2014). Good white people: The problem with middle-class white anti-racism. Suny Press.

Švelch, J. (2015). Negotiating a Glitch: Identifying and Using Glitches in Video Games with Microtransactions. In: New Perspectives in Game Studies: Proceedings of the Central and Eastern European Game Studies Conference, (pp. 55-70). Brno: Masarykova univerzita,

Todd, Z. (2016). An Indigenous feminist's take on the ontological turn:'Ontology'is just another word for colonialism. Joumal of historical sociology, 29(1), 4-22.

Tuck, E., \& Yang, K. (2012). Decolonization is not a metaphor. Decolonization: Indigeneity, education \& society, 1(1), 1-40.

Walcott, R. (2020). Sociology: Failed. Canadian Review of Sociology, 57(3), 484-486.

Zembylas, M. (2018). Affect, race, and white discomfort in schooling: Decolonial strategies for 'pedagogies of discomfort. Ethics and Education, 13(1), 86-104.

Disclosure statement: No potential conflict of interest was reported by the authors. 